Jurnal Sains Riset (JSR)

p-ISSN 2088-0952, e-ISSN 2714-531X

http://journal.unigha.ac.id/index.php/JSR

DOI. 10.47647/jsr.v10i12

\title{
UPAYA PENINGKATAN HASIL BELAJAR SISWA KELAS X MIPA-3 MATERI TEKS ANEKDOT PELAJARAN BAHASA INDONESIA MELALUI MODEL PEMBELAJARAN NUMBERED HEADS TOGETHER (NHT) PADA SMA NEGERI 1 KEMBANG TANJONG KABUPATEN PIDIE
}

\author{
Nur Chalidah \\ SMA Negeri 1 Kembang Tanjong \\ Email: nurchalidah471@gmail.com
}

\begin{abstract}
This study aims to determine the increase in the learning abilities of class X MIPA-3 students in Indonesian language subject Anecdotal Text for the 2018/2019 academic year through Numbered Heads Together (NHT) learning. This research was conducted at X MIPA-3 SMA Negeri 1 Kembang Tanjong, Pidie Regency, the research lasted for three months, from March to May 2019. The type of research used was Classroom Action Research (PTK) (the classroom action research) which consists of 2 cycles. The research subjects were students of class X MIPA-3 SMA Negeri 1 Kembang Tanjong Pidie Regency in the 2018/2019 academic year, namely 32 students. Data analysis used a comparative descriptive analysis technique by comparing the initial conditions with the results achieved in each cycle, cycle I and cycle II. The percentage of completeness obtained in the first cycle was $68.8 \%$ with a class average value of 71.9 and increased in the second cycle to $90.6 \%$ with a class average value of 78.6. In these two cycles, there was a significant change in activity and value acquisition when compared to the pre-cycle with learning completeness which only reached $53.1 \%$ and the average score was 66.6. Thus, through the application of Numbered Heads Together (NHT) learning can improve learning outcomes in Anecdote Text material for class X MIPA-3 students of SMA Negeri 1 Kembang Tanjong, Pidie Regency.
\end{abstract}

Keywords: Student Learning Outcomes, Anecdote Texts, Numbered Heads Together (NHT) learning model

\section{ABSTRAK}

Penelitian ini bertujuan untuk mengetahui peningkatan kemampuan belajar siswa kelas $\mathrm{X}$ MIPA-3 pelajaran Bahasa Indonesia materi Teks Anekdot Tahun Pelajaran 2018/2019 melalui pembelajaran Numbered Heads Together (NHT). Penelitian ini dilaksanakan di X MIPA-3 SMA Negeri 1 Kembang Tanjong Kabupaten Pidie, penelitian berlangsung selama tiga bulan yaitu sejak bulan Maret sampai dengan bulan Mei Tahun 2019. Jenis penelitian yang digunakan adalah Penelitian Tindakan Kelas (PTK) (the classroom action research) yang terdiri atas 2 siklus. Subyek penelitian adalah siswa kelas X MIPA-3 SMA Negeri 1 Kembang Tanjong Kabupaten Pidie Tahun Pelajaran 2018/2019 yakni sebanyak 32 siswa. Analisis data menggunakan teknik analisis deskriptif komparatif dengan membandingkan kondisi awal dengan hasil-hasil yang dicapai pada setiap siklus, siklus I dan siklus II. Persentase ketuntasan yang diperoleh pada siklus I sebesar 68,8\% dengan nilai rata-rata kelas sebesar 71,9 dan meningkat pada siklus II menjadi 90,6\% dengan nilai rata-rata kelas 78,6. 
Jurnal Sains Riset (JSR)

p-ISSN 2088-0952, e-ISSN 2714-531X

http://journal.unigha.ac.id/index.php/JSR

DOI. $10.47647 /$ jsr.v10i12

Pada kedua siklus ini terjadi perubahan aktivitas dan perolehan nilai yang signifikan bila dibandingkan dengan pra siklus dengan ketuntasan belajar yang hanya mencapai $53,1 \%$ dan nilai rata-rata adalah 66,6. Dengan demikian, melalui penerapan pembelajaran Numbered Heads Together (NHT) dapat meningkatkan hasil belajar pada materi Teks Anekdot pada siswa kelas X MIPA-3 SMA Negeri 1 Kembang Tanjong Kabupaten Pidie.

Kata Kunci: Hasil Belajar Siswa, Teks Anekdot, model pembelajaran Numbered Heads Together (NHT)

\section{PENDAHULUAN}

Peningkatan kualitas sumber daya menusia melalui pendidikan yang berkualitas. Dalam hal ini, pemerintah telah melaksanakan berbagai program dan menetapkan berbagai kebijakan untuk meningkatkan mutu pendidikan. Namun dalam kenyataannya kemampuan siswa masih rendah, hal ini terbukti masih banyak siswa yang nilai di ujian sekolah kurang dan belum mencapai standar yang telah ditetapkan terutama ditingkat Sekolah Menengah Atas (SMA). SMA Negeri 1 Kembang Tanjong yang letaknya di Jalan Tanah lapang Kembang Tanjong, menurut pengamatan penulis dari semua kelas hanya kelas $\mathrm{X}$ MIPA-3 yang kemampuan siswa masing rendah dari 32 orang siswa hanya 17 orang siswa yang tuntas atau hasil belajarnya baik, sedangkan lainnya masih rendah hasil belajarnya terutama pelajaran Bahasa Indonesia materi teks anekdot. Hal ini terbukti masih banyak siswa yang harus diremedialkan. Hal ini disebabkan oleh cara mengajar masih menggunakan metode, model, dan alat peraga yang belum relevan. Sehingga membuat siswa pasif, maka hasil belajarnya rendah. Sedangkan harapan penulis semua siswa bernilai baik dan tercapai KKM yang telah ditetapkan yaitu 70. Karena itulah, penulis tertarik untuk melakukan penelitian ini.

\section{METODE PENELITIAN}

Penelitian ini dilaksanakan di SMA Negeri 1 Kembang Tanjong di Kelas X MIPA-3 pada materi teks Anekdot.
Penelitian ini dilaksanakan selama 3 bulan yaitu bulan Maret sampai Mei 2019. Pelaksanaan penelitian dilakukan pada hari-hari efektif sesuai dengan jadwal jam pelajaran. Subjek penelitian adalah siswasiswi kelas X MIPA-3 tahun pelajaran 2018/2019, terdiri dari 12 orang siswa dan 20 orang siswi. Data yang diperoleh berasal dari siswa kelas X MIPA-3 SMA Negeri 1 kembang Tanjong. Alat pengumpul data yang digunakan adalah lembar instrumen aktifitas siswa dalam PBM, lembar instrumen PBM guru dan butir soal tes.

Analisis data yang digunakan dalam penelitian ini adalah teknik analisis deskriptif, yang meliputi:

1. Analisis deskriptif komparatif hasil belajar dengan cara membandingkan hasil belajar pada siklus I dengan siklus II dan membandingkan hasil belajar dengan indikator pada siklus I dan siklus II.

2. Analisis deskriptif kualitatif hasil observasi dengan cara membandingkan hasil observasi dan refleksi pada siklus I dan siklus II.

\section{HASIL PENELITIAN DAN PEMBAHASAN \\ Deskripsi Kondisi Awal}

Berdasarkan hasil belajar pada pra siklus dapat dianalisa sebagai berikut :

1. Nilai rata-rata kelas sebesar 66,6 dengan pencapaian ketuntasan 17 orang siswa atau $53 \%$ siswa yang mencapai KKM. Sedangkan 15 orang atau $47 \%$ 
Jurnal Sains Riset (JSR)

p-ISSN 2088-0952, e-ISSN 2714-531X

http://journal.unigha.ac.id/index.php/JSR

DOI. 10.47647/jsr.v10i12

siswa memperoleh nilai di bawah KKM.

2. Secara klasikal siswa belum mencapai ketuntasan belajar.

Berikut ini hasil belajar siswa sebelum tindakan

\begin{tabular}{|c|c|c|c|c|c|}
\hline $\begin{array}{c}\text { N } \\
\text { o }\end{array}$ & $\begin{array}{c}\text { Hasil } \\
\text { (Ang } \\
\text { ka) }\end{array}$ & $\begin{array}{c}\text { Hasil } \\
\text { (Hur } \\
\text { uf }\end{array}$ & $\begin{array}{c}\text { Arti } \\
\text { Lamb } \\
\text { ang }\end{array}$ & $\begin{array}{c}\text { Jum } \\
\text { lah } \\
\text { Sisw } \\
\text { a }\end{array}$ & $\begin{array}{c}\text { Pers } \\
\text { en }\end{array}$ \\
\hline 1 & $\begin{array}{c}85- \\
100\end{array}$ & A & $\begin{array}{c}\text { Sangat } \\
\text { baik }\end{array}$ & - & $0 \%$ \\
\hline 2 & $\begin{array}{c}75- \\
84\end{array}$ & B & Baik & 8 & $\begin{array}{c}25 \\
\%\end{array}$ \\
\hline 3 & $65-74$ & C & Cukup & 9 & $\begin{array}{c}28 \\
\%\end{array}$ \\
\hline 4 & $55-64$ & D & $\begin{array}{c}\text { Kuran } \\
\text { g }\end{array}$ & 15 & $\begin{array}{c}47 \\
\%\end{array}$ \\
\hline 5 & $<55$ & E & $\begin{array}{c}\text { Sangat } \\
\text { Kuran } \\
\text { g }\end{array}$ & - & $0 \%$ \\
\hline & & $\begin{array}{c}\text { Juml } \\
\text { ah }\end{array}$ & & 32 & 100 \\
$\%$
\end{tabular}

Sumber : Hasil tabulasi data April 2019

\section{Deskripsi Hasil Siklus I}

1. Hasil belajar siswa

\begin{tabular}{|c|c|c|c|c|c|}
\hline N & $\begin{array}{c}\text { Hasil } \\
\text { (Ang } \\
\text { ka) }\end{array}$ & $\begin{array}{c}\text { Hasi } \\
\text { ( } \\
\text { Hur } \\
\text { uf })\end{array}$ & $\begin{array}{c}\text { Arti } \\
\text { Lamba } \\
\text { ng }\end{array}$ & $\begin{array}{c}\text { Juml } \\
\text { ah } \\
\text { Sisw } \\
\text { a }\end{array}$ & $\begin{array}{c}\text { Pers } \\
\text { en }\end{array}$ \\
\hline 1 & $\begin{array}{c}85- \\
100\end{array}$ & A & $\begin{array}{c}\text { Sangat } \\
\text { baik }\end{array}$ & 5 & $\begin{array}{c}16 \\
\%\end{array}$ \\
\hline 2 & $75-84$ & B & Baik & 12 & $\begin{array}{c}37 \\
\%\end{array}$ \\
\hline 3 & $65-74$ & C & $\begin{array}{c}\text { Cukup } \\
\text { Dakn }\end{array}$ & 5 & $\begin{array}{c}16 \\
\%\end{array}$ \\
\hline 4 & $55-64$ & D & $\begin{array}{c}\text { Kuran } \\
\text { g }\end{array}$ & 10 & $\begin{array}{c}31 \\
\%\end{array}$ \\
\hline 5 & $<55$ & E & $\begin{array}{c}\text { Sangat } \\
\text { Kuran } \\
\text { g }\end{array}$ & - & - \\
\hline \multicolumn{7}{|c|}{ Jumlah } & 32 & $\begin{array}{c}100 \\
\%\end{array}$ \\
\hline
\end{tabular}

2019

Sumber: Hasil Tabulasi Data April

2. Nilai rata-rata pada siklus I meningkat menjadi 71,9 dengan pencapaian ketuntasan 22 orang siswa atau sebanyak 69\% siswa yang mencapai KKM.

\section{Deskripsi Hasil Siklus II}

1. Hasil belajar siswa

Tabel : Hasil Belajar Siswa Siklus II

\begin{tabular}{|c|c|c|c|c|c|}
\hline No & $\begin{array}{c}\text { Hasil } \\
\text { (Angka) }\end{array}$ & $\begin{array}{c}\text { Hasil } \\
\text { (Huruf) }\end{array}$ & Arti Lambang & $\begin{array}{c}\text { Jumla } \\
\text { h } \\
\text { Siswa }\end{array}$ & Persen \\
\hline 1 & $85-100$ & A & Sangat Baik & 14 & $43,8 \%$ \\
\hline 2 & $75-84$ & B & Baik & 9 & $28,1 \%$ \\
\hline 3 & $65-74$ & C & Cukup & 6 & $18,8 \%$ \\
\hline 4 & $55-64$ & D & Kurang & 3 & $9,4 \%$ \\
\hline 5 & $<55$ & E & Sangat Kurang & - & - \\
\hline & & & Jumlah & 32 & $100 \%$ \\
\hline
\end{tabular}

Sumber: Hasil Tabulasi Data Mei 2019

2. Nilai rata-rata pada siklus I meningkat menjadi 78,6 dengan pencapaian ketuntasan 29 orang siswa atau sebanyak 90,6\% siswa yang mencapai KKM.

Jika dibandingkan antara keadaan kondisi awal, siklus I dan siklus II, terdapat peningkatan dari awal sampai siklus II, Untuk lebih jelasnya dapat diperhatikan tabel di bawah ini:

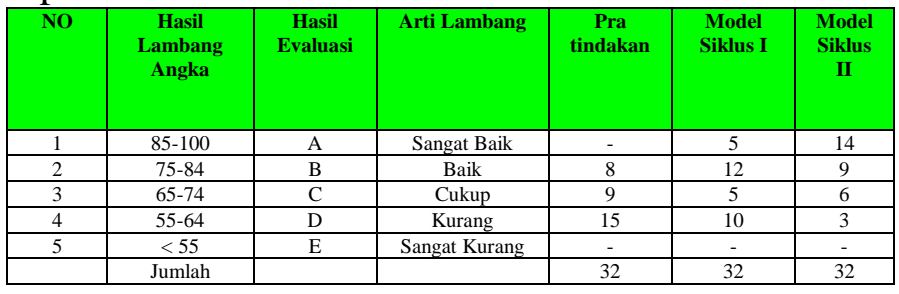

\section{PENUTUP}

Berdasarkan hasil penelitian, dapat disimpulkan bahwa melalui pembelajaran Numbered Heads Together dapat meningkatkan hasil belajar siswa kelas X MIPA-3 materi Teks Anekdot SMA Negeri 1 Kembang Tanjong Kabupaten Pidie Tahun Pelajaran 2018/2019. Terdapat peningkatan nilai rata-rata dari kondisi awal sampai siklus II. Dari 15 siswa pada kondisi awal yang tidak mencapai kriteria ketuntasan minimal menurun menjadi 10 orang pada siklus I dan menurun lagi hingga 3 orang pada siklus II. Ketiga orang ini memang diperlukan pembimbingan khusus untuk meningkatkan motivasi belajarnya 
Jurnal Sains Riset (JSR)

p-ISSN 2088-0952, e-ISSN 2714-531X

http://journal.unigha.ac.id/index.php/JSR

DOI. $10.47647 /$ jsr.v10i12

\section{DAFTAR PUSTAKA}

Anitah, 2008. Strategi Pembelajaran di SMA. Jakarata: Universitas Terbuka

Anita, Lie. 2002. Cooperative Learning. Jakarta: Grasindo.

Arikunto, Suharsini, 1991. Prosedur Penelitian : Suatu Pendekatan Praktek. Jakarta: Rineka Cipta

Budimansyah Dasim. 2002 Model Pembelajaran dan Penilaian. Siliwangi: HDB

BNSP, 2007. Standar Kompetensi dan kompetensi Dasar. Jakarta: Depdiknas

BNSP, 2007. Pedoman Penilaian Hasil Belajardi SMA. Jakarta: Depdiknas

BNSP, 2007. Pedoman Penilaian Hasil Belajar di SMA. Jakarta: Depdiknas

Dahar, RW. 1998. Teori - teori Belajar. Jakarta: Depdikbud

Dimyati dan Mudjiono, 1992. Strategi Belajar Mengajar. Jakarta: Depdikbud

Dinas Prop Jateng, 2004. Model- model Pembelajaran dan Penilaian. Makalah disampaikan pada Bintek Guru SMP bidang studi Fisika

Hadari, Nawawi. 2001. Metodologi Penelitian Bidang Sosial.

Yogyakarta: Gajah Mada University Press

Hidayat Komarudin,2002. Active Learning. Yogyakarta: Yappendi
Oemar, Hamalik.1993. Metode Mengajar dan Kesulitan-Kesulitan Belajar. Bandung: Tarsito

Pahyono, dkk. 2005. Strategi Pembelajaran efektif, Model pembelajaran Kooperatif Learning. Makalah disampaikan pada diklat guru kurikulum KBK diLPMP Jawa Tengah 